\title{
Rulers and Elites in Global History: Introductory Observations
}

\author{
Jeroen Duindam
}

\section{Introduction}

What persuades people to accept the authority of elites and governments? Coercion, inevitably is part of the answer: disobedience may be punished. Unsurprisingly, most definitions of the 'state' underline the monopoly of violence. ${ }^{1}$ However, violence and coercion are never the whole story: people are persuaded by the expectation of material advantages and charmed by the cultural allure or ideological appeal of political leadership. ${ }^{2}$ The balance between the ingredients of compliance-forced, instrumental, ideological-has been discussed throughout history. ${ }^{3}$ Confucius, Mencius, and their literati followers throughout Chinese history contrasted the way of the sage-king, ruling through moral example and righteousness, with the way of the hegemon, relying on punishments and rewards. Montesquieu related the ingredients of compliance to his three types of government: republic, monarchy, and despotism. Despotism, he argued, was held together only by fear, while monarchy depended on

1 Classic definitions in Max Weber, Wirtschaft und Gesellschaft: Grundriss der verstehenden Soziologie (Tübingen, 1972) 29; authoritative modern variants can be found in Michael Mann, 'The Autonomous Power of the State: Its Origins, Mechanisms and Results', in: States, War, and Capitalism: Studies in Political Sociology (Oxford and New York, 1988) 109-136, definition on 112; Michael Mann, The Sources of Social Power. Volume 1: A History of Power from the Beginning to AD 1760 (Cambridge, 1986) 26-27, 37; Gianfranco Poggi, The State: Its Nature, Development, and Prospects (Stanford, 1990) 9.

2 See the definitions and forms of 'Herrschaft' in Weber, Wirtschaft und Gesellschaft; Mann, Sources of Social Power, I, distinguishes four sources of social power 'ideological, economic, military, and political relationships' and presents these in a figure on 29; see an alternative view in David Cannadine, 'Introduction', in: David Cannadine and Simon Price, eds., Rituals of Royalty. Power and Ceremonial in Traditional Societies (Cambridge, 1987) 1-19 with a powerful definition of politics on 19 .

3 See a careful analysis by David Held, 'Power and Legitimacy', Political Theory and the Modern State (Cambridge, 1989) 99-157, note at 101-102 the continuum between coercion and ideal normative agreement, simplified to a threefold format here. 
honour - not only on the principles of honour and prestige, but also on the distribution of honours or benefits. The republic, finally, was animated by virtuean ideal that Montesquieu, after his disappointing visits to Europe's republics, situated in antiquity rather than in his own age. Ibn Khaldun's examination of the waxing and waning of dynasties likewise concentrates on the shifting mixture of willing adherence, violence, and interests among the followers of the dynasty. In each of these views, moreover, a cyclical alternation between types of rulers and governments was seen as distinctly possible or even as inevitable. ${ }^{4}$

Montesquieu placed his governments and their principles in a global view of climate and territory. He cautioned against the despotic tendencies of European rulers, but, in principle, located despotism in the East. His work is one of the stepping stones in the stereotyped European perception of 'Oriental despotism' stretching from Aristotle to the contemporary world. ${ }^{5}$ This book considers how coercion, interests, and ideology shaped the relationship between rulers and elites - the groups serving as their eyes, ears, and arms. It rejects the axiom that the admixture of coercion, interests and ideology differed necessarily either between East and West or between pre-modern and modern polities. Since the French Revolution, it has become common to view prerevolutionary dynastic polities as relying primarily on the use of force to keep in check exploited populations. Undoubtedly force was a conspicuous presence in pre-modern kingdoms and empires; nevertheless, infrastructural constraints seriously limited the ability of rulers to exercise their power. Even bullying rulers could use their coercive powers only intermittently and rarely throughout the entire realm. The conspicuous use of force by rulers' agents and the fear of retribution among the populace, always present, were not sufficient to integrate large territories around dynastic rulers.

This set of circumstances has been obscured because the ideological underpinnings of power changed fundamentally from the later eighteenth century onwards. Post-revolutionary states developed representative institutions, defined individual rights in written constitutions, and were characterized by an increasingly vocal public discussion. Understandably, they looked back with

4 See e.g. Mencius, P.J. Ivanhoe, ed., trans. Irene Bloom (New York, 2009) 33; Montesquieu, 'Des principes des trois gouvernements', De l'Esprit des Lois, in: Oeuvres completes (Paris, 1964) 536-540; Ibn Khaldun, The Muqaddimah. An Introduction to History, Franz Rosenthal, ed. (Princeton and Oxford, 1967).

5 Karl August Wittfogel, Oriental Despotism: A Comparative Study of Total Power (New Haven and London, 1957); see also the far more sophisticated notion of a 'high-level equilibrium trap' as developed in Mark Elvin, The Pattern of the Chinese Past: A Social and Economic Interpretation (Stanford, 1973). 
aversion on the political regimes of the earlier age. In their enthusiasm, they wildly overstated the powers of premodern rulers. We tend to forget that the instruments of control in the hands of ruling elites have been strengthening throughout the modern age. Consequently, pre-modern and modern cannot be seen simply in terms of a comprehensive contrast between enforced or voluntary compliance. ${ }^{6}$

Our joint study of dynastic centres throughout Eurasia questions the image of pre-modern polities as relying solely on coercion. It also leaves aside age-old images of the stagnant despotic East and dynamic and free West. We consider Eurasia as a zone of contact, characterized by a continuum of interaction and adaptation rather than as a continent sharply divided in unchanging extremes of East and West. States in early modern Europe have traditionally been understood by historians as bureaucracies and representative bodies gradually acquiring autonomous status and finally emancipating themselves from dynastic leadership. In the same tradition, Asian empires have been seen as 'palace polities' governed by the quirks of individual despots and liable to abrupt regime change, yet without the capability to generate profound and lasting reform. ${ }^{7}$ We leave aside these overstated contrasts, and zoom in on categories common to most polities in world history before 180o: a dynastic ruler at the centre, supported by a household comprising relatives, domestics, administrators, and soldiers, together forming the conspicuous heart of relatively loosely governed realms.

We examine rulership and elite identity in Eurasian polities, from Japan to Spain and from Muscovite Russia to the Vijayanagara empire, between ca. 1300 and 180o. This was an interconnected area long before the process of globalization encompassed other parts of the world. The period between the Mongol conquests and the rise of European global hegemony, moreover, coincides with increasingly dense contacts in this area as well as, more gradually, on the global scale. In most of the polities discussed, a relatively rich legacy of local sources is available; moreover, intensifying contacts gave rise to numerous outside perceptions supplementing these local sources. Major kingdoms and empires on

6 The work of Antonio Gramsci suggests strongly how power in any context depends on force as well as on 'manufactured' consent, see e.g. Steven J. Jones, Antonio Gramsci (London, 2006).

7 See Samuel E. Finer's impressive The History of Government from the Earliest Times (Oxford and New York, 1997) I, 34-58 with four forms of government (palace, forum, nobility and church) and their intermediate mixed forms. Although Finer uses the label 'palace polities' for European as well as Asian examples, there is a strong residue of this classic view, stressing the persistence of the palace-polity pattern in Asia while underlining reform and modernization in European monarchies. 
the Eurasian continent experienced heightened interaction, but only towards the end of this period did competing European powers gradually become the dominant presence everywhere, whether as conquerors and rulers, or as bullying traders. From the nineteenth century onwards, no major polity anywhere could arrange its internal affairs without considering 'Western' examples and interventions.

Early modern polities were loosely structured in comparison with the nation states emerging in the course of the nineteenth and twentieth centuries. Nevertheless, dynastic polities could show remarkable resilience over time and appear to have provided a strong focus for the numerous groups under their rule. Traditional historiography attributed 'absolute' power to these princes, yet this view has been undermined by revisionist research. Since the 1970s an increasing number of studies have shifted focus from the multiple laws and decrees generated by power centres to the responses at local levels. Without openly challenging central dynastic rule, local elites tended to bend the rules to fit their own interests. Providing local knowledge to the agents sent from the centre, they acted at the same time as middlemen advancing local interests at court. $^{8}$ Allying with the distant ruler was one of the strategies elites used to outdo their local rivals. Conversely, appeasing and rewarding local leaders was a manoeuvre commonly employed by rulers, who well knew that their force was limited and that inconclusive military action was likely to aggravate conflict.

Intermediaries were essential in holding together the dynastic ventureand their support was always in one way or another conditional. Ibn Khaldun outlined the evolving connections between rulers and their followers wielding sword or pen from generation to generation. Chinese literati stipulated the inevitable decline and fall of rulers no longer following the way of righteousness and forgetting the interests of their peoples-but they, too, knew that

8 Among the numerous titles revising the classic view of absolutism in Europe, see e.g. R.J.W. Evans, The Making of the Habsburg Monarchy 1550-1700. An Interpretation (Oxford, 1979); William Beik, Absolutism and Society in Seventeenth-Century France. State Power and Provincial Aristocracy in Languedoc (Cambridge, 1985); Roger C. Mettam, Power and Faction in Louis XIV's France (Oxford and New York, 1988); on the roles of elites in Qing China see e.g. Michael Szonyi, Practicing Kinship. Lineage and Descent in Late Imperial China (Stanford, 2002); Joseph Esherick and Mary Backus Rankin, eds., Chinese Local Elites and Patterns of Dominance (Berkeley, 1990); on the Ottoman empire see e.g. Karen Barkey, Empire of Difference. The Ottomans in Comparative Perspective (Cambridge, 2008); Baki Tezcan, The Second Ottoman Empire: Political and Social Transformation in the Early Modern World (Cambridge, 2010). 
popular rebellion would bring dynastic change only if it coalesced with elite discontent. While Montesquieu connected the presence of 'corps intermédiaires' specifically to European-style monarchy, we accept it as a necessity for all pre-modern polities. Our research concentrates on attempts of rulers and their advisors to create an exemplary centre based on redistribution and culturalreligious allure. ${ }^{9}$ This focus on dynasties and their connections among elites means that the population at large will be visible only through the lens of intermediary groups. The local connections of these elites and the wider perception of empire in the periphery do not form part of our project. Popular views of rulership and individual rulers will be considered at the level of literary traditions, but not through detailed study of local sources. This restriction is dictated by the need to maintain the focus of our wide-ranging comparative effort.

Our examination of the various interconnections of dynasties and intermediary elites will follow different points of departure: rulers with their relatives and servants at the heart of power; the admixture and conflict of worldly and spiritual leadership; power groups of clerks and soldiers mediating between the court and the provinces. A clash of interests occurred in and among these groups at many levels. Indeed, violent contestation was a frequent and inevitable element of dynastic power. We do not underplay these consistent conflicts, but use them as an opportunity to examine the recurring cycles of breakdown and consolidation, so dominant in political practice as well as in the political thinking of the pre-modern world.

With this jointly written study on dynastic rule and elites across Eurasia, we subscribe to the widely shared effort to make history more global in scope and perspectives. A powerful first generation of historians dealing with 'Big Structures, Large Processes, Huge Comparisons' and relying predominantly on English-language secondary literature was instrumental in creating a more unified view of world history. ${ }^{10}$ In recent decades, the global interest among faculty and students in history departments has given rise to numerous world history courses and world history textbooks. These overviews perform a very useful

In terms of Michael Doyle's epoch-making study of British imperialism, Empires (Ithaca and London, 1986): passing the 'Augustan threshold' and moving from conquest and military power to a consolidated stage of empire; see the discussion of Marlene Kurz, 'Gracious Sultan, Grateful Subjects: Spreading Ottoman Imperial “Ideology” throughout the Empire', Studia Islamica 3 (2012) 119-148.

10 The phrase is taken from Charles Tilly, Big Structures, Large Processes, Huge Comparisons (New York, 1984); in addition to Tilly himself, William H. McNeill, J.R. McNeill, and Jared Diamond can be mentioned as leading 'Big History' authors. 
service and are often written by teams of acknowledged regional experts, yet their ambitions are related to teaching rather than to research. ${ }^{11}$ World history textbooks expand the classic formula geographically, discussing political entities on a case-by-case level in every period, now including examples on a global scale. ${ }^{12}$ The experiences in various parts of the globe are usually integrated consistently only in terms of the process of globalization. Globalization, moreover, is typically related to the rising preponderance of Europe from the sixteenth century onwards.

The categories of sweeping synoptic world histories and overview-type textbooks provide a basis for undergraduate teaching. Many scholars embrace the wish to move to a more nuanced, empirical, and connected global perspective. Specialized scholarship, however, demands language competence and a careful contextual reading of primary sources in their original languages. Researchers who want to reach beyond regional and national perspectives need to learn more languages. While this can be achieved on a limited scale, the requirement prohibits a global perspective. No single scholar can master the key languages of the Eurasian continent, let alone of the world. Global history, therefore, appears to be a contradiction in terms: history can be global only if it

11 Diego Olstein, Thinking History Globally (Houndmills, 2015) connects world history primarily to 'big history' using the world as its unit, and to the effort to make history teaching more comprehensive by integrating the entire globe in introductory courses. He sees global history as examining the interconnections and issues related to the process of comparison, and hence not necessarily encompassing the entire world. See the more powerfully phrased, often cited, but somewhat partisan earlier statement by Bruce Mazlish, 'Comparing Global History to World History', The Journal of Interdisciplinary History 28 (1998) 385-395, and the sensible discussion in Kenneth Pomeranz and Daniel Segal, 'World History. Departures and Variations', in: Douglas Northrop, ed., A Companion to World History (Malden and Oxford, 2012) 15-31. Comparative history, like world history and global history, has its own journals and book series: e.g. Comparative Studies in Society and History at http://cssh.lsa.umich.edu/; Comparativ. Zeitschrift für Globalgeschichte und vergleichende Gesellschaftsforschung; http://research.uni-leipzig.de/comparativ/; Journal of World History at http://www.uhpress.hawaii.edu/t-journal-of-world-history.aspx; Journal of Global History at http://journals.cambridge.org/action/displayJournal?jid=JGH. In these publications, numerous studies of varying breadth and impact can be found. A brief look at the contents suggests that Mazlish's clear separation no longer applies: both world and global history predominantly fit the paradigm of connected or entangled history, to be discussed at some length below.

12 However, see more recent attempts to provide coherent and analytical overviews of world history, Stephen Morillo, Frameworks of World History. Networks, Hierarchies, Culture (Oxford, 2013); Merry Wiesner-Hanks, A Concise History of the World (Cambridge, 2015). 
disrespects one its most fundamental tenets. Conferences offer a way out of the predicament by bringing together specialists who collectively address questions on the basis of first-hand knowledge of materials. Conference volumes, however, tend to conform to the format of a general introduction briefly indicating comparative themes, followed by a series of individual contributions outlining a single case.

Which methods and perspectives can help to bridge the gap between the requirement of language competence and the pursuit of global themes in history? Two very different approaches have dominated global history since the 199os: the debate about the timing and nature of worldwide economic divergences and the history of increased global interactions. ${ }^{13}$ How does our book relate to these examples?

\section{$\mathbf{1}$ \\ Connections and Comparisons}

An enduring paradigm was created by Fernand Braudel, who presented the Mediterranean as a zone of contact rather than as a maritime boundary separating cultures. Other such marine zones of contact have since been defined: the Atlantic, Pacific, and Indian Oceans, and more recently also river deltas. ${ }^{14}$ The same reasoning has been applied to landmasses, notably the steppe zone at the heart of the Eurasian continent. The interest in these frontier zones leads naturally to the instruments, vessels, and protagonists of contact: trade routes, maps, ships, horses, traders, soldiers, artists, and interpreters. The artefacts moving along these corridors have likewise been studied: seeds, plants, germs, feathers, weapons, ceramics, silver, paintings. Finally, the movement of ideas, artistic styles, and religious creeds has been charted. ${ }^{15}$ Mobility and

13 See on the latter recently Jeremy Adelman, 'Global History or the History of Globalization? (Review)', Journal of World History 27 (2016) 701-708.

14 Fernand Braudel, La Méditerranée et le monde méditerranéen à l'époque de Philippe II (Paris, 1949); André Wink, 'From the Mediterranean to the Indian Ocean: Medieval History in Geographic Perspective', Comparative Studies in Society and History 44, no. 3 (2002) 416445; Edward A. Alpers, The Indian Ocean in World History (Oxford and New York, 2013); David Christian, 'Silk Roads or Steppe Roads? The Silk Roads in World History', Journal of World History 11, no. 1 (2000) 1-26; Michael Adas, 'Continuity and Transformation: Colonial Rice Frontiers and Their Environmental Impact on the Great River Deltas of Mainland Southeast Asia', in: Edmund Burke and Kenneth Pomeranz, eds., The Environment and World History (Berkeley, 2009) 191-207.

15 See e.g. many publications by Ebba Koch on cultural-artistic connections between Europe 
contact entail actions, responses, misperceptions, and adaptations: this notion, often present in the history of global contacts, has been expanded by histoire croisée to include not only the objects of study, but also the views developed by researchers. ${ }^{16}$ The reflection engendered by the interlacing of concepts derived from different cultures, it is suggested, will help scholars to critically review their categories of thought and comparison.

Sanjay Subrahmanyam and Serge Gruzinski pioneered an empirically rich global branch of 'connected history', zooming in on the trajectories, meeting points, agents, and objects of exchange. Their approach neatly fits the current interests in materiality, networks, subjectivity and individual agency, microhistory and life-writing. It stresses the processes of exchange: encounters, perceptions, learning, and translation. This actor-based perspective traces the impact of encounters on all participants involved, and thus effectively circumvents the traditional focus on the national state. ${ }^{17}$ Rather than concentrating on interacting states, the analysis leaves room for local, peripheral, and metropolitan actors in all ranks and positions. Cultures and polities are seen as the result of ongoing interaction rather than as unchanging building blocks. Subrahmanyam has argued that among groups with different social modes and cultural standards a middle ground was created. 'Commensurability' took shape at particular locations and was furthered by specific actors, who themselves changed in the process—a process described as métissage by Gruzinski. ${ }^{18}$ By

and West Asia and in West Asia; Timothy Brook, Vermeer's Hat: The Seventeenth Century and the Dawn of the Global World (New York, 2008); on religion recently Nile Green, Terrains of Exchange: Religious Economies of Global Islam (Oxford, 2014).

16 Michael Werner and Bénédicte Zimmermann, 'Penser l'histoire croisée: entre empirie et réflexivité', Annales. Histoire, Sciences Sociales 58, no. 1(2003) 7-36 at 17, developed in the final part of the article.

17 Still the main focus in Victor Lieberman, Strange Parallels: Southeast Asia in Global Context, c. 80o-1830, 2 vols. (Cambridge, 2003-2010); see Ramya Sreenivasan, 'A South Asianist's Response to Lieberman's Strange Parallels', The Journal of Asian Studies 70, no. 4 (2011) 983-993.

18 Serge Gruzinski, 'Faire de l'histoire dans un monde globalisé', Annales. Histoire, Sciences Sociales 66, no. 4 (2011) 1081-1091; Gruzinski, 'Les mondes mêlés de la monarchie catholique et autres "connected histories"', Annales. Histoire, Sciences Sociales 56, no. 1 (2001) 85-117; in the same volume Sanjay Subrahmanyam, 'Du Tage au Gange au Xvie siècle: une conjoncture millénariste à l' échelle eurasiatique', Annales. Histoire, Sciences Sociales 56, no. 1 (2001) 51-84; Sanjay Subrahmanyam, 'Connected Histories: Notes towards a Reconfiguration of Early Modern Eurasia', Modern Asian Studies 31, no. 3 (1997) 735762; Sanjay Subrahmanyam, From Tagus to the Ganges: Explorations in Connected History (Oxford, 2011); Sanjay Subrahmanyam, Courtly Encounters: Translating Courtliness and 
charting in detail the trajectories and experiences of actors and objects, connected history shows at close range where the global and the local met, and how this process affected all concerned. Globalization never was a simple unidirectional process.

The contextual depth of global connected history has been possible only through the mastery of languages. The logic of contiguity and exchange limits the number of languages required, but these will still present a challenge. The history of connections can adopt a long-term and global perspective, yet its most successful examples focus on a specific connection in a limited time frame. ${ }^{19}$ Hence they also raise the issue of synchronicity and 'time' in history. ${ }^{20}$ Does the fifteenth century have a global meaning? ${ }^{21}$ Can we discern a global 'early modernity'? ${ }^{22}$ Was there any affinity between the heterodox worlds of

Violence in Early Modern Eurasia (Cambridge Mass., 2012); on métissage and related terms see Philippe Delisle, 'Introduction au dossier: "Acculturation, syncrétisme, métissage, créolisation: Amérique, Océanie, xvie - xvie siècles"', Histoire et missions chrétiennes 5 (2008) 9-13, and the other contributions to this issue. The notion of a 'middle ground' was introduced by Richard White, The Middle Ground: Indians, Empires, and Republics in the Great Lakes Region, 1650-1815 (Cambridge, 1991); see a recent different view: Michael A. McDonnell, Masters of Empire: Great Lakes Indians and the Making of America (New York, 2015).

19 See examples from the brief and powerful comprehensive overview by J.R. McNeill and W.H. McNeill, The Human Web: A Bird's-Eye View of World History (New York, 2003) to the focused seventeenth-century story based on six Vermeer paintings by Brook, Vermeer's Hat. Gruzinski, 'Les mondes mêlés de la monarchie catholique', 97. Conversely, see publications focusing on a moment in time bringing together geographically unconnected examples: Patrick Boucheron, Julien Loiseau, Pierre Monnet, and Yann Potin, Histoire du monde au Xve siècle (Paris, 20o9); Shmuel N. Eisenstadt, The Origins and Diversity of Axial Age Civilizations (New York, 1986); see a critical appraisal by Antony Black, 'The "Axial Period": What Was It and What Does It Signify?', The Review of Politics 70 (2008) 23-39.

See a recent statement by Sanjay Subrahmanyam, 'Waiting for the Simorgh: Comparisons, Connections, and the Early Modern', in: Sven Trakulhun and Ralph Weber, eds., Delimiting Modernities: Conceptual Challenges and Regional Responses (Lanham, 2015) 99-121; Jeroen Duindam, 'Early Modern Europe: Beyond the Strictures of Modernization and National Historiography', European History Quarterly 40, no. 4 (2010) 6o6-623; Shmuel N. Eisenstadt and Wolfgang Schluchter, 'Introduction: Paths to Early Modernities: A Comparative View', Daedalus 127, no. 3 (1998) 1-18; Jack Goldstone, "The Problem of the "Early Modern" World', Journal of the Economic and Social History of the Orient 41, no. 3 (1998) 249-284; Timothy Brook, 'Medievality and the Chinese Sense of History', The Medieval History Journal 1, no. 1 (1998) 145-164; On-Cho Ng, "The Epochal Concept of "Early Modernity" and the 
Rudolf II, Akbar, and their contemporaries, or between the well-ordered universes of Louis XIV and the Kangxi Emperor?23 Did the crises striking the world in the course of the seventeenth century reflect global causes? ${ }^{24}$ Was the wave of disturbances and intellectual ferment in the later eighteenth century more than a European or Atlantic export product? ${ }^{25}$

Connected history has been a prime mover in global history, but its very success highlights some limitations inherent in the method. Key views introduced by leading connected historians about the construction of contacts and commensurability as a multilateral process have been widely accepted, and the multiplication of studies now mostly adds colour and detail to an accepted formula. New books zooming in on globetrotters, places of contact, artefacts or ideas moving across the globe can no longer have the freshness, vigour, and impact of the pioneering first studies. The current proliferation of examples suggests the appeal of connected history as well as its limited potential for innovation.

The 'Rise of the West' and its more balanced comparative offshoots have formed a rival and equally influential approach in the global history spectrum. ${ }^{26}$ The 'great divergence' is an incontestable fact at least from the later eighteenth century onwards, and this phenomenon has rightly been singled

Intellectual History of Late Imperial China', Journal of World History 14, no. 1 (2003) 3761; Subrahmanyam, 'Connected Histories'; Craig Clunas, 'Review Essay: Modernity Global and Local: Consumption and the Rise of the West', American Historical Review 104, no. 5 (1999) 1497-1511. See also Clunas's Empire of Great Brightness: Visual and Material Cultures of Ming China, 1368-1644 (Honolulu, 2007) 7-9, offering a description that perfectly seems to match contemporary Europe.

23 Joachim Bouvet, Histoire de l'empereur de la Chine: présentée au roy (The Hague, 1699) in his preface compares Louis and his Chinese fellow-ruler; on connections and movements of ideas about governance see Antje Flüchter and Susan Richter, ed., Structures on the Move. Technologies of Governance in Transcultural Encounter (Heidelberg, 2012).

24 Geoffrey Parker, Global Crisis: War, Climate Change and Catastrophe in the Seventeenth Century (New Haven, 2013).

25 David Armitage and Sanjay Subrahmanyam, eds., The Age of Revolutions in Global Context, c. 1760-1840 (Houndmills, 2010).

26 Many titles can be cited. William H. McNeill, The Rise of the West: A History of the Human Community (Chicago, 1963) and the author's retrospective view 'World History and the Rise and Fall of the West', Journal of World History 9, no. 2 (1998) 215-236; Kenneth Pomeranz, The Great Divergence: China, Europe, and the Making of the Modern World Economy (Princeton, 200o); see a recent contribution by Peer Vries, State, Economy and the Great Divergence: Great Britain and China, 1680s-1850s (London and New York, 2015); an institutional-economic approach in J.L. van Zanden, The Long Road to the Industrial Revolution. The European Economy in a Global Perspective, 1000-1800 (Leiden and Boston, 
out for research. However, while this debate is indubitably global in its relevance, the question it seeks to answer imposes a concentration of research efforts on successful cases. Within Europe the Dutch Republic and England get more attention than Spain or France, while Central and Eastern Europe remain largely invisible. In Asia, the Jiangnan area and the Southeastern seaboard of China occupy centre stage. The Mughal and Ottoman empires are only marginally included, as ranking below the benchmark set by Europe and China, commonly seen as the two major contenders. Most other parts of the world are included only as component parts of the emerging worldwide Europedominated trade network.

Recently, scholars have reinvigorated the 'great divergence' approach by infusing it with the vocabulary of 'New Institutional Economics' and by extending it to political and military change. The institutional and military angles make clear that the gradual ascent of Europe cannot be understood only as an economic process. Was European military organization the main factor in the 'Rise of the West'? Or was European military success itself the consequence of larger social, institutional, cultural, and economic divergences between Europe and other parts of the globe?27 Such thorny questions may remain insoluble. Explaining voyages of discovery and military expansion is easier than defining structural differences in mentality or social structure between the 'East' and 'West' - categories that upon further inspection break down into myriads of smaller entities with highly differentiated social and cultural patterns. Explaining success entails explaining failure elsewhere and risks repeating clichés about the unchanging East versus European dynamism. Often it adopts as a starting point criteria inferred from European success: civic corporations, representative institutions, bustling markets, entrepreneurial acumen. The current economic format of the debate has the benefit of consistency and methodological rigour, but the reduced scope engendered by the concentration on economic success stories limits the potential of the divergence paradigm for global history.

Which other models for global comparative history can be found? The most influential comparative historian with a global view in the 1950s undoubtedly was Arnold Toynbee, whose multi-volume Study of History reached wide

2009), and in Philip T. Hoffman, Why Did Europe Conquer the World? (Princeton, 2015); a wide-ranging succinct statement by Wolfgang Reinhard, Staatsmacht und Staatskredit. Kulturelle Tradition und politische Moderne (Heidelberg, 2017).

27 The question of divergence and breakthrough can be pursued in relation to mentalities, reformation, scientific revolution, and so on, see e.g. H. Floris Cohen, The Rise of Modern Science Explained (Cambridge, 2015). 
audiences in its abridged edition. ${ }^{28}$ Toynbee considered the cyclical rise and fall of 'civilizations' rather than the rise of the modern state or the linear cultural evolution of mankind. Following the lead of Max Weber's global typologies of power and religion, sociologists were equally ambitious, although they were interested primarily in the rise of modernity. S.N. Eisenstadt published a wide-ranging comparison of empires, which, however, failed to integrate primary sources and adhered to a classic evolutionist stance. ${ }^{29}$ The volume edited two decades later by the same author on the 'Axial age' did include focused contributions by regional specialists dealing with the breakthroughs in thinking occurring between the sixth and fourth centuries BCE in polities across the globe. The Harvard sociologist Barrington Moore published an influential comparative examination of modernization and the rise of totalitarianism; his pupils Charles Tilly and Theda Skocpol continued carrying the torch of comparative historical sociology. ${ }^{30}$ In the early post-war years, many anthropologists were intent on gathering information on 'primitive' societies worldwide that would allow systematic cross-cultural analysis. George P. Murdock's 'Human Relation Area Files' and the Anthropological Atlas underline the remarkable ambitions of this project. ${ }^{31}$ In addition to these attempts to lay the groundwork for global anthropological comparison, elaborate regional typologies of kinship and political systems were published for Africa. ${ }^{32}$ In an equally systematic, less evolutionary, and more focused style, Jack Goody brought together

28 Arnold Toynbee, A Study of History (Oxford and London, 1934-1961) twelve vols.

29 Shmuel N. Eisenstadt, The Political Systems of Empires. The Rise and Fall of the Historical Bureaucratic Societies (New York, 1963); see the critical review by Eric Wolf in the American Anthropologist 67 (1965) 172-176.

30 Barrington Moore, Social Origins of Dictatorship and Democracy: Lord and Peasant in the Making of the Modern World (Boston, 1966); Charles Tilly, The Vendée: A Sociological Analysis of the Counterrevolution of 1793 (Cambridge, Mass., 1964) followed by an impressive series of comparative and conceptually influential works; Theda Skocpol, States and Social Revolutions: A Comparative Analysis of France, Russia and China (Cambridge, 1979).

31 George. P. Murdock, Ethnographic Atlas: A Summary (Pittsburgh, 1967); G.P. Murdock, 'Feasibility and Implementation of Comparative Community Research: With Special Reference to the Human Relations Area Files', American Sociological Review 15 (1950) 713720 , and an updated version and presentation of these files at http://www.bu.edu/library/ guide/hraf/.

32 M. Fortes and E.E. Evans-Pritchard, African Political Systems (London, New York, Toronto, 1940); A.R. Radcliffe-Brown and D. Forde, eds., African Systems of Kinship and Marriage (London, New York, Toronto, 1950); see Caroline B. Brettell, 'Anthropology, Migration, and Comparative Consciousness', in: Rita Felski and Susan Stanford Friedman, eds., Compar- 
contributions on succession to high office in Africa, adding an introduction of remarkable acuity and global relevance. ${ }^{33}$

Political centralization, stability, and breakdown - always present to some extent in the institutional economists' explanation of global divergencehave been fruitfully examined in several comparative works of near-global dimension. ${ }^{34}$ Jack Goldstone's analysis of cases of 'state breakdown' in Europe and Asia defines demography as the single universal cause, but explains in detail how numerous other characteristics of state breakdown derived from this first cause. Moreover, Goldstone's model does not aim to explain either the rise of modernity or the head start of any specific region: it explains the process of state breakdown in several roughly comparable polities and can be tested by examining cases in other periods and regions. In an even more ambitious endeavour, Victor Lieberman postulates six 'convergences' in the political development of Eurasian polities between 800 and $1800 . .^{35}$ All underwent roughly synchronic phases of expansion, consolidation, centralization, cultural integration, and commercialization. The world, or in any case Eurasia, apparently followed a parallel rhythm. Lieberman, in addition, distinguishes between the Eurasian polities profoundly influenced by nomadic steppe peoples' conquests (the 'exposed' zone) and those less structurally vulnerable in this respect (the 'protected' zone). His comparison of largely unconnected 'strange parallels' focused on the state rather than on the actors and objects figuring prominently in connected history, yet it stays within the perspective of contiguity, by stipulating an overarching relationship across the Eurasian continent, and by excluding areas outside of this admittedly huge perimeter.

ison: Theories, Approaches, Uses (Baltimore, 2013) 292-314 at 294-196 on Murdock and 'British structural functionalism' and their demise after the 196os.

Jack Goody, ed., Succession to High Office (Cambridge, 1966); see the adaptation of Goody's model to China by Patricia B. Ebrey, 'Succession to High Office: The Chinese Case', in: David R. Olson and Michael Cole, eds., Technology, Literacy, and the Evolution of Society: Implications of the Work of Jack Goody (Mahwah, 2006) 49-71.

Finer, History of Government; Mann, Sources of Social Power, see also more recently Victoria Tin-bor Hui, War and State Formation in Ancient China and Early Modern Europe (Cambridge, 2005).

35 Jack A. Goldstone, Revolution and Rebellion in the Early Modern World (Berkeley and Los Angeles, 1991); Lieberman, Strange Parallels; also see his 'What "Strange Parallels" Sought to Accomplish', The Journal of Asian Studies 70, no. 4 (2011) 931-938 and Goldstone on Lieberman: 'New Patterns in Global History: A Review Essay on Strange Parallels by Victor Lieberman', Cliodynamics: The Journal of Theoretical and Mathematical History 1, no. 1 (2010) 92-102. 
Neither positivist evolutionary anthropology, nor Weberian sociological typology, or Toynbee's particular style of comparing civilizations survived the 196os and 1970s unscathed. The aspirations and style of comparative research repelled adherents of the cultural turn, post-structuralism, post-modernism, and post-colonialism. Not without reason, early anthropology and comparison practised in the colonial age have been described as the intellectual auxiliaries of European hegemony, academic offshoots of imperial 'othering.' ${ }^{36}$ Modern critics have presented state- or civilization-based comparison in similar terms, as rephrasing ethnic and national clichés and, in its worst form, as serving as an 'intellectually refurbished form of eurocentrism.' ${ }^{37}$ Anthropologists, at the forefront of the cultural turn and abhorring evolutionism, broadly rejected the goal of systematic comparison held by their predecessors. ${ }^{38}$ Exceptional among these critics, Clifford Geertz developed his own form of smaller-scale comparison. On the basis of his close familiarity with Morocco and Indonesia Geertz disentangled the varieties of Islam in these different cultures and combined comparison with a densely textured description of cultural practices. ${ }^{39}$ Geertz's intelligent middle way suggests that comparison should not be discarded without careful consideration; the models presented by Goldstone and Lieberman, too, underline the strength of the comparative perspective.

Many characteristics attributed to comparative history, such as the concentration on national states, or the facile evolutionary contrast between different societies, can be seen as typical for an entire generation of historians. The problems of 'othering' and hegemony, too, are not peculiar to comparison. We need to take a more careful look at the objectives, problems, and promises of comparison. ${ }^{40}$ First of all, it should be made clear that there is no single dominant paradigm of comparison. ${ }^{41}$ Comparison comes in many forms and does not appear to have a single, broadly accepted method. At one extreme, current

36 See a modern restatement of this verdict in Micol Seigel, 'Beyond Compare: Comparative Method after the Transnational Turn', Radical History Review 91 (2005) 62-9o.

37 Gruzinski, 'Les mondes mêlés de la monarchie catholique', 86; Seigel, 'Beyond Compare'.

38 Aram A. Yengoyan, 'Comparison and Its Discontents', in: Aram A. Yengoyan, ed., Modes of Comparison: Theory \& Practice (Ann Arbor, 2006) 137-157.

39 Clifford Geertz, Islam Observed:Religious Development in Morocco and Indonesia (Chicago, 1971).

40 Eisenstadt, The Origins and Diversity of Axial Age Civilizations; See critique in Robert N. Bellah, 'What Is Axial about the Axial Age?', European Journal of Sociology / Archives Européennes de Sociologie 46, no. 1 (2005) 69-89, and Eisenstadt's response: 'The Axial Conundrum between Transcendental Visions and Vicissitudes of Their Institutionalizations: Constructive and Destructive Possibilities', Análise Social 46, no. 199 (2011) 201-217. Raymond Grew, 'The Case for Comparing Histories', The American Historical Review 85, 
comparatists can adopt a highly systemic social science approach, by rigidly defining causal factors and tabulating their absence or presence in different cases. $^{42}$ This 'Boolean minimization' suggests a laboratory-like precision, an impression strengthened by graphs, tables, and mathematical formulae. The critical issue here is the designation of isolated variables and the decision whether these variables were relevant in the cases under scrutiny. This operation, presupposing clear and distinct social processes, leaves little room for the quirks and incidents so prominent in human interaction and motivation.

At the other end of the spectrum, comparisons can be found that stay close to the empirical orientation of history, with the full panoply of literature, published and unpublished sources. They zoom in on local contexts with multiple and unpredictable actors, hesitate before postulating sweeping outcomes, and would never venture to make predictions. Their results, less crispy-clear than those of the Boolean school, reflect a profoundly different attitude. The one point of agreement among the extended and ill-disciplined family of comparatists seems to be the aspiration to break free of the restrictive framework of the development over time of a single state or region. Beyond this shared aim, purposes and methods of the contrasting forms of comparison differ widely. Surely, the more empirical comparative historians are far closer in mentality to the family of connected historians than to their Boolean brethren. ${ }^{43}$

no. 4 (1980) 763-778; Grew, 'On Rereading an Earlier Essay', in: Aram A. Yengoyan, ed., Modes of Comparison: Theory \& Practice (Ann Arbor, 2006) 118-136.

42 Charles C. Ragin, The Comparative Method: Moving Beyond Qualitative and Quantitative Strategies (Oakland, 1989); Alrik Thiem, 'Unifying Configurational Comparative Methods. Generalized-Set Qualitative Comparative Analysis', Sociological Methods \& Research 43, no. 2 (2014) 313-337; see an overview of current comparative approaches in sociology: Masamichi Sasaki, Jack Goldstone, Ekkart Zimmermann, and Stephen K. Sanderson, eds., Concise Encyclopedia of Comparative Sociology (Leiden and Boston, 2014).

43 Theda Skocpol and Margaret Somers, 'The Uses of Comparative History in Macrosocial Inquiry', Comparative Studies in Society and History 22, no. 2 (1980) 174-197; Michael Hanagan, 'Shall I Compare Thee ...?" Problems of Comparative Historical Analysis', International Review of Social History 56, no. 1 (2011) 133-146; Philippa Levine, 'Is Comparative History Possible?', History and Theory 53, no. 3 (2014) 331-347; see a sceptical assessment of scientific-style comparison and its 'false precision' in Linda Gordon, 'A Meditation on Comparison in Historical Scholarship', in: Felski and Friedman, eds., Comparison:Theories, Approaches, Uses, 315-335 at 318-319; Victor de Munck, 'Introduction: Units for Describing and Analyzing Culture and Society', Ethnology 39, no. 4 (2000) 279-292 underlines the differences between comparison and cross-cultural analysis, discerns the approaches in ethnology and ethnography, and defends a reinvigorated cross-cultural analysis. 
The lack of unity in inspiration, methods, and purposes of comparative history is hardly new. There was little consistency in the outlook of early prophets and critics of comparison, from John Stuart Mill, James Frazer, and Émile Durkheim to Franz Boas, Max Weber, or Marc Bloch. Those interested in comparison usually stressed the need to explain rather than to understand, but they shared this attitude with many others. In an 1896 lecture, Boas distinguished comparative and historical methods in a way that seems particularly relevant for the current state of global and connected histories. ${ }^{44}$ He warned against assuming without further evidence a shared origin of habits found in distant areas. However, he also cautioned his audience that remarkable similarities should not be construed unthinkingly as reflecting universal human patterns. Boas's argument distinguishing comparative and historical methods was reiterated in 1951 by A.R. Radcliffe-Brown. Typically, both authors ended their talks on a critical note. In 1896 Boas stated that 'The solid work is still all before us'; in 1951 Radcliffe-Brown was equally modest:

It will be only in an integrated and organized study in which historical studies and sociological studies are combined that we shall be able to reach a real understanding of the development of human society, and this we do not yet have. ${ }^{45}$

44 Franz Boas, 'The Limitations of the Comparative Method of Anthropology', Science 4, no. 103 (1896) 901-908. See a similar discussion based on Ferdinand de Saussure and linguistics in the work of Marc Bloch, 'Pour une histoire comparée des sociétés européennes', Revue de synthèse historique 46 (1928) 15-50, taken up in William H. Sewell, 'Marc Bloch and the Logic of Comparative History', History and Theory 6, no. 2 (1967) 208-218; Alette Olin Hill and Boyd H. Hill, 'Marc Bloch and Comparative History', The American Historical Review 85, no. 4 (1980) 828-846 with the ensuing heated debate printed in the same volume $847-857$.

45 Alfred Reginald Radcliffe-Brown, Method in Social Anthropology; Selected Essays (Chicago, 1958) 129. While Radcliffe-Brown's aspiration to arrive at universal laws of human behaviour reflects the ambitions of his nineteenth-century predecessors and fits awkwardly modern (postmodern?) academic orientations, his statement rings true. Jack Goody, Audrey Richards, Max Gluckman, and other practitioners of comparison in the 1950s and 196 os still show the intellectual vigour and rigour of this approach. On the anthropological paradigm of comparison and its demise see Yengoyan, 'Comparison and Its Discontents', 137-156; Richard Handler, 'The Uses of Incommensurability in Anthropology', in: Felski and Friedman, eds., Comparison: Theories, Approaches, Uses, 271-291, and Caroline B. Brettell, 'Anthropology, Migration, and Comparative Consciousness' in the same volume at 292-314. 
Writing in 2017, much the same can be said: the variety of approaches and perspectives has multiplied, but the same basic tension between a painstaking reconstruction of the local and the allure of wider comparative vistas persists. The discrepancies in methods between historians, area specialists, and social scientists appear larger than ever. Partisans of computer modelling develop high-tech visualizations and predictions of human behaviour while most historians observe these feats with bewildered scepticism and stress the naivety of the ambition to harness the myriad variables dictating individual and social behaviour in this way. Neither did historians among themselves develop consistent and widely accepted models of comparison. Leading authorities from Marc Bloch (1928) to John Elliott (1991) have asserted the imperative need to transgress the limitations of national and regional histories, pleading for broader comparative frameworks. Both authors actively contributed to the field with major works, combining detailed observation with a wide horizon. Their pleas for comparative history, however, ended on the same modest note their anthropologist-colleagues had voiced a generation or so earlier: this is a necessary and important ambition rather than a project within easy reach. ${ }^{46}$

Comparison is an essential aspect of human cognition; it is a permanent presence in our daily lives ${ }^{47}$ All historians are comparatists: they implicitly compare their own age with the worlds they study. Particularly for scholars examining areas distant from their place of residence, comparison is always present. Yet the implicit form of comparative reflection inherent in history usually remains invisible to the reader. Once comparison is voiced explicitly, it often takes an unequal or asymmetrical form: powerful and knowledgeable statements about one period or region are placed in a wider perspective that betrays limited or outdated knowledge about the other cases cited. The main

46 Bloch, 'Pour une histoire comparée des sociétés européennes'; Marc Bloch, Les Rois Thaumaturges (Paris, 1924); Marc Bloch, La sociétéféodale (Paris, 1939); John H. Elliott, National and Comparative History. An Inaugural Lecture Delivered before the University of Oxford on 10 May 1991 (Oxford, 1991) and by the same author Richelieu and Olivares (Cambridge, 1984); Empires of the Atlantic World: Britain and Spain in America, 1492-1830 (New Haven, 2006). Also see Hanagan, "Shall I Compare Thee ...?" and Levine, 'Is Comparative History Possible?' for further discussion and examples of recent work. See the lucid discussion of empire by Susan Reynolds, 'Empires: A Problem of Comparative History', Historical Research 79, no. 204 (2006) 151-165 at 165 stating that: 'The real argument against comparison is that it is such hard work, especially when it goes over different periods and demands a range of different skills ...'; see a similar statement with different conclusions by Gordon, 'A Meditation on Comparison in Historical Scholarship', at 314, 317.

A point well made in Susan Stanford Friedman, 'Why not compare?', in: Felski and Friedman, eds., Comparison: Theories, Approaches, Uses, 34-45, at 36-37. 
object of research is framed in a regional or global tour d'horizon, yet comparison is not pursued either systematically or symmetrically. ${ }^{48}$ Asymmetrical comparison tends to reconfirm clichés (French 'absolutism', the Prussian Beamtenstaat, Sultanic omnipotence) because it mostly relies on outdated scholarship. Ideally comparison is symmetrical: it should rely on the equal or near-equal knowledge of all components entering into the examination. ${ }^{49}$ The requirement of equal knowledge, however, is not accomplished easily. It is further complicated by the need to define criteria of comparison that do not reflect the experiences of one region only. These challenges help to explain why comparison remains unfinished business; however, they should not dissuade us from engaging in this important endeavour.

Modern comparatists no longer follow Murdock or Radcliffe-Brown in their quest for fixed 'laws' of human behaviour. Nevertheless, comparison challenges us to explain how different responses to equivalent circumstances arose across the globe, and how and why these changed over time. The balanced answer to the global challenge developed by practitioners of connected history has great cogency and appeal. It effectively supersedes older expansion history, yet it cannot, and does not aim to, answer the questions raised by comparative history. Rather than pursuing connections, the authors of this volume accept the ambitious comparative project stipulated by Radcliffe-Brown, seeking patterns and explanations in human behaviour-in our case in the changing relationships between rulers and elites in Eurasian polities. ${ }^{50}$

\section{$2 \quad$ The Imperial Turn-A Conceptual Muddle?}

This leaves us with the question of scale and units of comparison. There is a long tradition of comparing 'civilizations' or 'cultures', of which Arnold Toynbee's works are a relatively recent specimen. Toynbee reckoned among his examples the works of Ibn Khaldun, with whom he shared an interest in the

48 See for instance the comparative observations on France by two leading Qing historians, Mark C. Elliott, Emperor Qianlong: Son of Heaven, Man of the World (New York and San Francisco, 2009) 38, 40; R. Kent Guy, Qing Governors and Their Provinces: The Evolution of Territorial Administration in China, 1644-1796 (Seattle, 2010) 360-361.

49 See, however, the stress on 'light' and unequal comparison in Gordon, 'A Meditation on Comparison in Historical Scholarship', 321 and 333 .

50 Christopher Beckwith, Empires of the Silk Road:A History of Central Eurasia from the Bronze Age to the Present (Princeton, 2009). 
rise and fall of polities. ${ }^{51}$ Toynbee's work, highly influential and popular at the time of its composition, has been all but forgotten. ${ }^{52}$ The definition of 'civilizations' and 'cultures' is highly contested; boundaries of these somewhat elusive concepts cannot be drawn on the map without hesitation. Ideal types representing 'essential characteristics' stand at the beginning as well as at the end of comparisons of civilizations. While Toynbee's achievement was considerable and introduced many lucid ideas, it seems ill-advised to build comparison on civilizations or cultures, fuzzy entities with contested definitions. National history, as has become clear, has been an impediment rather than a support for comparative history. The modern concept of the state, moreover, more often than not gives rise to misunderstandings when applied to pre-modern history. Empires and kingdoms appear as more historical and are explicitly related to dynastic power - polities governed by emperors or kings. Nevertheless, the cultural connotations of these European terms raise the question whether they can be used elsewhere. And what exactly is empire?

Global developments in the last three decades, and particularly after 1989, have restored an old theme to research agendas and public interest: the rise and fall of empires. The increasing importance of transnational phenomena, including multinationals and NGOS as well as problems such as global warming, contagious diseases, and the emerging terrorist threat made clear that the nation state no longer occupied the key position it could claim in the two centuries following the French Revolution. European laws and economic arrangements had reached a point where they undercut the sovereignty of member states. In addition to these gradual processes, the fall of the Berlin Wall and the implosion of the Soviet Union suddenly promoted the USA to global hegemony. Was this 'unipolar moment', coinciding with the global dominance of liberal capitalism, a brief interlude, or would it last? This question was hotly debated in policy circles and in academia. ${ }^{53}$

The decline of one world power not only allowed the hegemony of another: it also gave room to new conflicts and movements across the globe. Former communist leaders and their adversaries in Yugoslavia and elsewhere kindled

$51 \quad$ Robert Irwin, 'Toynbee and Ibn Khaldun', Middle Eastern Studies 33, no. 3 (1997) 461-479.

$5^{2}$ Krishan Kumar, 'The Return of Civilization—and of Arnold Toynbee?', Comparative Studies in Society and History 56, no. 4 (2014) 815-843.

53 See e.g. Charles Krauthammer, 'The Unipolar Moment', Foreign Affairs 70, no. 1 (1990) 2333; and the same author, 'The Unipolar Moment Revisited', The National Interest 70 (2002) $5^{-18}$; discussion of unipolarity, hegemony, and empire as typologies in Daniel H. Nexon and Thomas Wright, 'What's at Stake in the American Empire Debate', American Political Science Review 101, no. 2 (2007) 253-271. 
the powers of nationalism to acquire legitimacy. Religious and national antagonisms, contained and used instrumentally under the umbrella of Cold War contestation, re-emerged with the erosion of the overarching imperial structures.

The 'unipolar moment' of American preponderance invited policy makers and scholars to consider the question how empires in history consolidated and maintained their position - or how they had failed to do so. The post-Cold War flaring of conflicts raised the question how far-flung empires had managed ethnic and religious diversity. The divided sovereignty and the federal forms of law emerging in the European Union changed the perspective of scholars on earlier polities. The Holy Roman Empire, long considered a painful anachronism by German national historians, a Nachzügler in the formation of national states, could now be re-evaluated as a Vorreiter of European federalism and supranational law-making. ${ }^{4}$ These multiple stimuli gave rise to an explosion of literature on empire, ranging from arcane academic discussions to popular books and political debates..$^{55}$ In this process, many forms of rule were grouped together under the flexible label of 'empire'. In the 199os the study of empires became so popular that it has been labelled the 'imperial turn. ${ }^{56}$ Some of the complications of this renewed interest in empire will be discussed below.

The term empire, or imperium, originally referred primarily to the military command granted by the Roman senate to leading magistrates. The practice of styling a commander as imperator ended with the rise of Augustus, when the term became restricted to the Roman princeps. Following the demise of the Roman Empire in the West, Charlemagne's coronation in 800 restored the title. After a brief respite, it was to be used for the suzerain of the Holy Roman Empire from 962 to 1806. During almost the entire period, the Empire held the

54 Johannes Burkhardt, 'Europäischer Nachzügler oder institutioneller Vorreiter? Plädoyer für einen neuen Entwicklungsdiskurs zur konstruktiven Doppelstaatlichkeit des frühmodernen Reiches', in: Matthias Schnettger, ed., Imperium Romanum-Irregulare Corpus-Teutscher Reichs-Staat: das Alte Reich im Verständnis der Zeitgenossen und der Historiographie (Mainz, 2002) 297-316; a positive reappraisal of the late nineteenth-century Danube monarchy can be found in Pieter M. Judson, The Habsburg Empire: A New History (Cambridge Mass., 2016) and Judson, “"Where Our Commonality Is Necessary ...”: Rethinking the End of the Habsburg Monarchy', Austrian History Yearbook 48 (2017) 1-21.

55 See the digression of Barroso on empire in the European Parliament on July 102007 : https://www.youtube.com/watch?v=-I8MiT-GgRU.

56 See e.g. Alan Mikhail and Christine M. Philliou, "The Ottoman Empire and the Imperial Turn', Comparative Studies in Society and History 54, no. 4 (2012) 721-745; see Mazlish, 'Comparing Global History to World History' using the term on 395. 
only accepted imperial title of Europe, until the Russian Czar, Napoleon, and the Austrian Habsburgs claimed the honour-an initiative followed by others in Europe and elsewhere in the course of the nineteenth century. ${ }^{57}$ The shared dominion of pope and emperor was never unchallenged; neither did it ever encompass Europe as a whole. Nevertheless, it held a universal ambition related intimately to Christianity. Other imperial leaders, more powerful than the European pope and emperor, cherished a similarly exalted and unique status. In the margins of Europe, Byzantine emperors maintained their presence in Constantinople while the imperial dignity in the West disappeared. Their legacy was taken over by the Ottomans after Mehmed II's conquest of the Second Rome. Subsequently Selim I's conquest of Cairo in 1517 also brought the mantle of the prophet to Ottoman Istanbul. While the Ottoman Sultans did not consistently use the title of Caliph in these centuries, they did in practice act as kings of kings, and henceforth would not think of accepting other princes as equals. Neither did the Chinese emperor, who was seen as ruling 'all under heaven' (tianxia). Emperors thus underlined their special status as the single supreme lord ruling over multiple kings. This was the assertion made in $221 \mathrm{BC}$ by the King of Qin, who upon subjecting the Chinese kingdoms added the title of huangdi (emperor) to the title tianzi (son of heaven) introduced by the preceding Zhou dynasty. Charlemagne, too, claimed to rule over kings. This idea of the supreme ruler as a king of kings is reflected in the Persian titles shahanshah and padishah, adopted by later Islamic rulers. Emperors presented their dominion as unlimited and universal. ${ }^{58}$ They ruled over kings and included numerous peoples in their domains.

This view of emperors as kings-of-kings, combining various peoples under their rule, returns in most modern typologies of empires. In one sentence, Stephen Howe provides a definition of empire that comprises elements recurring in almost all modern definitions:

... a large, composite, multi-ethnic or multinational political unit, usually created by conquest, and divided between a dominant centre and subordinate, sometimes far distant, peripheries. ${ }^{59}$

57 See Reynolds, 'Empires: A Problem of Comparative History' for a sensible overview and discussion, typically written by a relative outsider.

$5^{8}$ See Peter Fibiger Bang and Dariusz Kolodziejczyk, eds., Universal Empire: A Comparative Approach to Imperial Culture and Representation in Eurasian History (Cambridge, 2012).

59 Stephen Howe, Empire: A Very Short Introduction (Oxford, 2002) 30. 
The large area, mixed populations, and centre-periphery structure appear as the elements common to all empires. Conquest, clearly, cannot be seen as a trait characterizing all empires in every stage of their existence. Many longlasting empires would disappear from the list should we accept as empires only polities at the time of their rise to power when they actively vanquished their neighbours. The centre-periphery relationship, moreover, has been understood in contradictory ways. Charles Tilly stresses the indirect nature of imperial rule, the inevitable presence of intermediary elites, and the relative autonomy of some of these groups. In his view, imperial rule tends to be flexible and diverse, taking different shapes in core lands, contiguous provinces, and more distant areas. Finally at the frontier, tributary allies can become provincesand vice versa. The levels of allegiance and the forms of governance vary from the heart of the empire to its outlying regions. ${ }^{60}$ Tilly's stress on indirect rule, differentiation, and negotiation is not universally accepted. Alexander Motyl, mostly examining nineteenth-century empires, stresses the 'absolutist' nature of imperial rule. ${ }^{61}$

Are empires necessarily characterized by a specific form of government? The only polity that was formally known as an empire in Europe before Napoleon's coronation in 1804, the Holy Roman or German Empire, developed into a federation of princes approaching sovereign status, under the suzerainty of a prestigious elected emperor. Much the same can be said about the political structure closest to an empire in medieval West Asia. Following the decline of the Abbasid Caliphate in the tenth century, a 'Muslim Commonwealth' appeared in which a variety of dynasties still formally recognized the overlordship of the Caliph. ${ }^{62}$ Other examples show that military-commercial empires did not even necessarily have a royal or imperial leader. The Dutch and Venetian seaborne empires cultivated a form of elite self-government. The Portuguese, Spanish, French, and English polities were ruled by kings rather than by emperors, yet they did acquire overseas empires. Can the European seaborne empires, themselves a mixed gathering, be compared with Asian land-based empires under the sultan, the shah, or the son of heaven? And can this heterogeneous selection of pre-modern empires be grouped into one category with nineteenth-

6o Charles Tilly, 'How Empires End', in: Karen Barkey and Mark von Hagen, eds., After Empire: Multiethnic Societies and Nation-building: The Soviet Union and the Russian, Ottoman and Habsburg Empires (Boulder, 1997) 1-12, definition at 3-4.

61 Alexander Motyl, 'Thinking about Empires', in: Barkey and Hagen, After Empire, 19-29.

62 Hugh N. Kennedy, 'The Structure of Politics in the Muslim Commonwealth', The Prophet and the Age of the Caliphates: The Islamic Near East from the Sixth to the Eleventh Century (Harlow, London, New York, 2004) 198-209. 
century 'imperialist' powers dominating the world with the instruments created by the Industrial and French Revolutions? Or with twentieth-century empires based on the threat of nuclear retaliation? In terms of scale, contiguity, political organization, and economic basis, the differences surely are more striking than the similarities. Within a more limited region and period, the question of scale needs to be asked. In what ways, if any, did scale make a difference? Managing distance and diversity were challenges in particular for large-scale empires, whereas a smaller scale has been related to representative institutions. ${ }^{63}$

The literature on empires in global history displays a lack of precision. The term 'Habsburg Empire', for example, can be related to several distinct political entities. It may refer to the Habsburg kings of Spain (1516-1713) under whose authority an overseas world empire was conquered—governed by Bourbon princes after 1713. Yet sometimes it points to the junior Austrian branch of the Habsburgs, successors of Charles v's younger brother Ferdinand, who ruled their own hereditary duchies and crowns in Central Europe. After the senior Spanish branch became extinct, the Austrian Habsburgs pushed back the Ottomans in South-eastern Europe: their expanded territory was redefined as the Kaiserthum Österreich which existed from 1804 until 1867. The last Habsburgs from 1867 onwards ruled the Danube Monarchy as king of Hungary and emperor of Austria. Additionally, the Habsburgs famously held the elective imperial dignity of the Holy Roman Empire for almost the entire period between 1440 and 1806 . Most authors use the term Habsburg Empire when they refer either to the Spanish World Empire or to the Danube monarchy, the first as specimen of emerging European global empires, the second as an empire often perceived as doomed because of its anachronistic multinational structure. ${ }^{64}$ The only polity that was formally labelled an empire in Europe has systematically been sidelined in the recent academic vogue for empire.

Which polities do we accept as empires? Once we follow the terms (empire or its equivalents) or concepts (kings of kings, unbounded universal authority) used by contemporaries, only a limited number of polities qualify. The varying and inconsistent criteria provided by modern scholarship, conversely, include empires without dynastic rulers or universal missions. Empires have been defined in so many ways to fit very different discussions: the remarkable story of conquests throughout history, the rise, fall, and sometimes remark-

\footnotetext{
63 See e.g. David Stasavage, States of Credit: Size, Power, and the Development of European Polities (Princeton, 2011).

64 See a more positive view in Judson, Habsburg Empire.
} 
able persistence of Asian land empires, the rise of Europe's global hegemony, European competition in Africa and Asia, the 'End of Empire' and the concomitant rise of nation-states from the early twentieth century onwards, the rise of expansionist dictatorships in the twentieth century, various deaths and resuscitations of empire in our own age. ${ }^{65}$ Clearly it is essential to limit the context of discussion before moving forward.

\section{3}

\section{Eurasian Rulers and Elites}

The 'imperial turn', coinciding with a waxing public interest in histories of rising and declining powers, cannot be reduced to a single coherent formula. Several elements of the muddled debate about empire need to be sorted out first. First of all, we need to ascertain whether Eurasian polities shared certain specific characteristics. Does the label 'Eurasian' imply more than geographical scope? Secondly, choices regarding the scale and units of comparison will be clarified.

Great Asian continental empires share most characteristics listed in Howe's definition: a large territory, multi-ethnicity and a plurality of religions, a conspicuous centre ruling over peripheral provinces. In addition, however, these empires were all in one way or another connected to the steppe heartlands of the continent. They originated in the conquests of nomads moving outwards from Inner Asia, they were shaped in response to such conquests, or they reflected a combination of these influences over time. From Istanbul to Beijing, and from Moscow to Delhi, the legacies of steppe peoples, most prominently the Mongols, can be traced. Great empires tended to arise in the areas labelled by Lieberman as the 'exposed zone' rather than in the 'protected zone' more distant from the Mongol onslaught. ${ }^{66}$ A Turco-Mongol stamp united empires across the Asian continent; the ways in which nomadic empires adopted the administrative techniques of sedentary empires and, alternatively, the persistence of the nomadic legacies in such sedentary empires, have been discussed in numerous publications. ${ }^{67}$

65 Joseph Esherick, 'How the Qing Became China', in: Joseph Esherick, Hasan Kayali, and Eric Van Young, eds., Empire to Nation. Historical Perspectives on the Making of the Modern World (Lanham, 2006) 229-259.

66 Victor Lieberman, 'Protected Rimlands and Exposed Zones: Reconfiguring Premodern Eurasia', Comparative Studies in Society and History 50, no. 3 (2008) 692-723.

67 See e.g. J.F. Fletcher, 'Turco-Mongolian Monarchic Tradition in the Ottoman Empire', Harvard Journal of Ukrainian Studies 3-4 (1979-1980) 236-251; J.F. Fletcher, 'The Mongols: 
This view of Eurasia is centred on the connections between Inner Asian nomads and the great continental empires. Alternatively, Eurasia can be understood simply as the entirety of Europe and Asia, from the British Isles to Japan and from the Northern fringes of Russia to South India. In this open geographic sense, the area encompasses both 'European sea nomads' and 'Inner Asian land nomads'.68 More generally, it comprehends at least three overlapping and interacting worlds that looked upon themselves as the heart of civilization as they knew and defined it: the 'Sinosphere' of 'all under heaven' governed by the Chinese emperor or at least under the umbrella of Chinese culture; the multipolar world of Arabic-Persianate-Islamicate empires in West and South Asia; the splintered universe of Christian Europe. ${ }^{69}$ None of these worlds was lastingly brought under the control of a single imperial centre; yet in each of these worlds a shared cultural-religious vocabulary facilitated communication and understanding. Points and routes of contact between the zones were numerous - moving from one extreme of Eurasia to another, however, was more difficult in terms of travel and communication than moving between contiguous zones. We exclude the European seaborne empires from our examination; they are the subject of a separate tradition of scholarship integrating other zones of the globe. While Central Asia certainly forms part of our initiative, only Jos Gommans focuses on the nomadic legacy per se. Our common challenge has been to study the changing relationships between rulers and elites in Europe, West and South Asia, and East Asia, the three interconnected Eurasian macro-regions centred around their own universalist creeds.

This leaves open the question of scale, and the units of comparison. The macro-regions were never consolidated under the authority of a single political centre. Which political entities would qualify as units of analysis? Should we define them on the basis of territory, population, levels of administrative

Ecological and Social Perspectives', Harvard Journal of Asiatic Studies 46, no. 1 (1986) 11-5o; Beckwith, Empires of the Silk Road; more recently and with a focus on periodization and fiscal-administrative techniques: Nicola Di Cosmo, 'State Formation and Periodization in Inner Asian History', Journal of World History 10, no. 1 (1999) 1-40; see David Robinson on the Mongol legacy in Ming China: David M. Robinson, ed., Culture, Courtiers, and Competition: The Ming Court (1368-1644) (Cambridge Mass., 2008); Robinson, Martial Spectacles of the Ming Court (Cambridge Mass., 2013). Forthcoming: Nicola Di Cosmo and Michael Maas, Empires and Exchanges in Eurasian Late Antiquity: Rome, China, Iran, and the Steppes ca. 250-750 CE (Cambridge, 2018).

68 Lieberman, 'Protected Rimlands and Exposed Zones', 721.

69 In this sense, Eurasia coincides with the 'old web' as outlined in McNeill and McNeill, The Human Web. 
expertise or economic development? Conversely, contemporary perceptions could have been used to single out the truly imperial centres in each of the macro-regions. In the end we decided to leave aside such criteria and concentrate on the complications of governance in polities of diverse scale and nature. ${ }^{70}$ Pre-modern empires, kingdoms, and even duchies shared many characteristics. The modern nation state, with its universal rights and duties for a population perceived as uniform and unified, contrasts not only with most definitions of empire, but more generally also with the practice of rule in pre-modern polities. ${ }^{71}$ Limited infrastructures and means of communication dictated relatively loose forms of government. Diversity was accepted pragmatically and grudgingly rather than embraced as an ideal, yet the notion of governing many peoples, demonstrated through the accumulation of titles and dignities, was universally appreciated. Even a relatively small European dynastic polity, such as the Burgundian state, combined under its authority a series of smaller entities ruled under different titles and with diverse rights and privileges. Until the seventeenth century, personal unions, combining several principalities under one ruler, were common in Europe. Louis XIV, ruling a kingdom most often pictured as highly unified, explicitly addressed subjects in the plural as mes peuples. Negotiating with different groups and regions and granting them a variety of special rights was the standard practice, at times experienced as the curse, of most European states until the later eighteenth century.72

Daniel Nexon, one among the many voices in the current discussion on Empire, noticed the parallel between European composite states and the imperial style of relatively loose government. ${ }^{73}$ He suggested the relevance of a 'dynastic-imperial pathway' for European as well as Asian polities. Expanding on Tilly's definition of empire and Elliott's understanding of European

70 See a similar line of reasoning recently expressed by Giuseppe Marcocci, 'Too Much to Rule: States and Empires across the Early Modern World', Journal of Early Modern History 2o, no. 6 (2016) 511-525.

71 Pamela Crossley, 'Nationality and Difference in China: The Post-Imperial Dilemma', in: Joshua Fogel, ed., The Teleology of the Modern Nation-State:Japan and China (Philadelphia, 2005) $138-158$.

72 England is the exception here, with its national parliament not based as elsewhere on the delegates from regional assemblies.

73 Daniel H. Nexon, The Struggle for Power in Early Modern Europe: Religious Conflict, Dynastic Empires, and International Change (Princeton, 2009) combines ideas from Tilly with the work of historians such as Koenigsberger and Elliott, e.g.J.H. Elliott, 'A Europe of Composite Monarchies', Past \& Present 137, no. 1 (1992) 48-71; H.G. Koenigsberger, Politicians and Virtuosi. Essays in Early Modern History (London, 1986). 
'composite monarchies', Nexon underlined the presence of intermediary elites, the differentiated forms of indirect rule, and the primary orientation of each region on the centre rather than laterally on other regions. In empires as well as in dynastic composite monarchies, the political centre functioned as a hub, a meeting point for the realm as a whole. Nexon suggests that the dynastic centre could speak with many voices, if necessary adopting a different register for every region, because of the sparse lateral contacts among regional elites. The Manchu rulers of Qing China offer an example of this practice: they addressed China proper with the well-established language of Confucianism and literati culture, but engaged the peoples in the periphery on the basis of shared Manchu-Mongol cultural legacies. Yet even the Austrian Habsburgs, in their far smaller portfolio of Central European territories, adapted to the different traditions of their subjects. In addition, most dynastic centres did adopt and broadcast an overarching artistic-cultural-religious style as the hallmark of their authority, in architecture, dress, or speech, which allowed locals to adopt the central style without forfeiting their own idioms and agendas. ${ }^{74}$

Global historians who focus on connections and zones of contact have expressed serious misgivings about comparative history. Comparative historians, on the other hand, do not necessarily endorse the need for global history. Globalists who focus on economic divergence, finally, do not always integrate primary sources in the languages from the areas they study. We hope to combine the best of two worlds: the cultural nuance and proximity to contemporaries' experiences foregrounded by the connected history paradigm, and the power of the bird's eye view that can only come with comparison. Our questions privilege comparison rather than contact. Without the benefit of contextual knowledge, best acquired through language competences, primary sources, and a focus on actors and their worldviews, global history remains an empty shell; without the questions emerging only as a result of a distanced comparative perspective, global history is reduced to an accumulation of individual cases. Our challenge will be to persistently combine these perspectives.

This book can be read as a coherent statement on our theme, yet it combines contrasting choices and methods. Every contribution, written against the background of the author's specialized knowledge and in view of the specific themes discussed, chooses a different emphasis and varies in terms of

74 See examples in Kurz, 'Gracious Sultan, Grateful Subjects'; Yuri Pines, The Everlasting Empire: The Political Culture of Ancient China and Its Imperial Legacy (Princeton, 2012). 
geographical scope or period. These themes, choices, and perspectives of the chapters will be outlined below.

The first chapter flows from Jeroen Duindam's earlier work on the court. ${ }^{75}$ How could this conspicuous centre attract diverse audiences and attach them lastingly to the dynastic endeavour? Who could control this process, and who profited from it? Duindam selectively adopts a wider comparative perspective. African examples show that some aspects of the court, such as redistribution and ritual, can be found anywhere. Moreover, they reveal that comparison disregarding contiguity, scale, and development can lead to relevant outcomes. The responsibility for rain and cosmic phenomena and the taboo on meeting the ruler's gaze or using his name can be found in the Chinese empire as well as in African kingship. Yet wholly different patterns of governance existed here: imperial China with its multi-tiered hierarchy of officeholders operating at distance through written communication versus African smaller-scale interactive and oral 'open-air government'. The chapter on courts, moreover, aims to move comparison beyond establishing similarities and differences: contrasting practises are reassessed as functional equivalents, similarities inspected to reveal profound particularities. At this second level of examination comparison renders more powerful results. Duindam's chapter uses examples from the whole period, but there is a preponderance of the centuries after 1500 .

In the second chapter, Peter Rietbergen, whose early research dealt with the papal bureaucracy, traces the all-important relationship between religious power and imperial rule. ${ }^{76}$ Supreme rule was always, in one way or another, related to religious worldviews. Moreover, this nexus was an essential ingredient both in the representation of rulership and in the willingness of the populace to abide by their prince's wishes. Rietbergen questions modern Trennungsdenken: religion cannot easily be separated from other human pursuits. Modern attitudes towards religion, moreover, can complicate global comparison. Secular scholars may be tempted to downplay the impact of religion, or

75 See e.g. Jeroen Duindam, 'Royal Courts', in: Hamish Scott, ed., The Oxford Handbook of Early Modern European History. 1350-1750. Volume II: Cultures and Power (Oxford, 2015) 440-477; Duindam, Vienna and Versailles. The Courts of Europe's Dynastic Rivals 1550-1780 (Cambridge, 2003); Duindam, Dynasties. A Global History of Power 1300-1800 (Cambridge, 2016) and at http://www.brill.com/publications/rulers-elites titles in the Brill series Rulers \& Elites.

76 See e.g. P.J.A.N. Rietbergen, Pausen, prelaten, bureaucraten: geschiedenis van het pausschap en de Pauselijke Staat in de zeventiende eeuw (Nijmegen, 1983); Rietbergen, Religion and Culture in Baroque Rome: Barberini Propaganda Policies (Leiden, 2005). 
see it largely in instrumental terms. Conversely, scholars who identify strongly with certain religious positions in past and present may find it difficult to treat holy writ with academic distance. These diverging attitudes, furthermore, sometimes overlap with the contrast between 'the West and the Rest'. While Rietbergen follows the geographical scope and period of the project, he views his theme through the actions and attitudes of specific powerholders. His cast of personalities is concentrated in the sixteenth and seventeenth centuries.

Jos Gommans, who wrote extensively on warfare and soldiery in the frontier area between India, Iran, and Central Asia, in the third chapter considers the 'people of the sword'.77 This elite was essential for all major pre-modern polities to secure compliance through the threat of violence. Gommans's chapter provides a counterpoint to the project's comparative priority: it moves closer to the connected paradigm. He charts the rise, spread, and concomitant change of the particularly successful Chinggisid warband during its march through Eurasia. How did the encounters of the Chinggisid warband with sedentary polities on the margins of the Central Eurasian steppe change the relationship between rulers and warriors? Gommans takes into account the self-perception of the groups he examines, and uses terms that were meaningful for contemporaries. Also, his chapter maintains the centrality of one region: the Inner Asian military experience is the lens through which other regions are perceived - a procedure more often used implicitly for the European example.

The 'people of the pen', the administrators supporting princely power, are examined by Maaike van Berkel, whose published work deals with the Abbasid administration as well as with the Mamluks. ${ }^{78}$ Together, the chapters of Gommans and Van Berkel cover the two most essential corps intermédiaires. ${ }^{79}$ Van

77 See e.g. Jos J.L. Gommans, The Rise of the Indo-Afghan Empire: C. 1710-1780 (Leiden, 1995); Jos J.L. Gommans, Mughal Warfare: Indian Frontiers and Highroads to Empire 1500-1700 (London, 2002); Jos J.L. Gommans and D.H.A. Kolff, eds., Warfare and Weaponry in South Asia 1000-1800 (Oxford, 2001).

78 Maaike van Berkel, 'Accountants and Men of Letters. Status and Position of Civil Servants in Early Tenth Century Baghdad' (PhD dissertation, University of Amsterdam, 2003); Maaike van Berkel, Nadia El Cheikh, Hugh Kennedy and Letizia Osti, Crisis and Continuity at the 'Abbāsid Court. Formal and Informal Politics in the Caliphate of al-Muqtadir (295320/9o8-932) (Leiden, 2013); see also on the Mamluks e.g. Maaike van Berkel, 'Opening up a World of Knowledge. Mamluk Encyclopaedias and their Readers', in: J. König, ed., Encyclopaedism from Antiquity to Renaissance (Cambridge, 2013) 357-378.

It should be noted that neither in these two contributions, nor in Rietbergen's chap- 
Berkel pursues Gommans's focus on self-perception and identity by looking at the people of the pen through a Quellengattung: advice literature. Do these literary emanations of elite administrators in our various macro-regions reveal similar ideals? How did elite clerks position themselves vis-à-vis the prince and other elite groupings? And, finally, how can these self-perceptions be placed in the social constellations from which they emerged, and what do they tell us about legitimacy and compliance? Van Berkel highlights the strong position of literate elite clerks throughout Asia and notes the tardy and hesitant arrival of their compeers in Europe. In line with her previous research expertise, she restricts her comparative analysis to the centuries before 16oo, ending at the point where Europe was entering a phase of accelerated state building and government by paper.

Our collective work, starting with the central dynastic establishment and its relationship with spiritual power, before moving to the intermediaries of sword and pen, ends with two shorter chapters: a focused comparison of two dynasties and an examination of kingship narratives. Marie Favereau and Liesbeth Geevers outline the 'construction' of two dynasties with profoundly different reputations: the Habsburgs and the Jochids (Chinggis Khan's Golden Horde descendants). Can we view these two lines of rulers as variants of a single concept, or do they reflect incommensurable ideas and practises? The sustained co-operative effort allows the chapter to stay close to primary sources in the relevant languages, while at the same time it raises several relevant comparative observations. Finally, Richard van Leeuwen's comparative chapter on narratives involving royalty shows how many themes of this book recur in fiction. ${ }^{80}$ Van Leeuwen's comprehensive view of narratives reflects to some extent the popular perception of rulership. Moreover, his chapter on princes, heroes, viziers, and concubines in narratives moves beyond the comparative: it unveils connections between the geographical regions of our project. Similar themes recur in many places in a variety of shapes - a fact that could be established with relative ease, but remains more difficult to explain in detail.

ter, do religious intermediary elites occupy centre stage. This reflects practical reasons rather than any sound methodological consideration: we regret the absence of a chapter devoted to this group. This conclusion became clear in the course of our project, when we encountered major differences in function and status of religious specialists in the macroregions of Eurasia. Clearly, these positions shifted too, see e.g. A. Azfar Moin, The Millennial Sovereign. Sacred Kingship \& Sainthood in Islam (New York, 2012) on the Mongol impact on the relations between rulers and 'ulama'.

80 See van Leeuwen's Narratives of Kingship in Eurasian Empires 1300-1800 (Leiden and Boston, 2017) also published in the context of our joint research programme. 
Van Leeuwen's chapter appropriately brings together themes discussed throughout the book and prepares the ground for the conclusion. Which shared aspects of rulership can be traced across Eurasia, which divergences strike the eye, and what can they tell us about relations between rulers and elites? The conclusion provides answers and reviews the relevance of our experiment for current paradigms in global history. 